\title{
UJI EFEKTIVITAS EKSTRAK KULIT BATANG PULAI (Alstonia scolaris) TERHADAP HAMA Plutella xylostella
}

\author{
Yustina M.S.W. Pu' u' ${ }^{1}$, Anastasia Lili Tangguk ${ }^{2}$ \\ Yus_puu@yahoo.com
}

\section{Program Studi Agroteknologi, Fakultas Pertanian-Universitas Flores}

\begin{abstract}
The aim of this study is to find outthe effectiveness and concentration of Pulai stem extract (Alstoniascolaris) upon the pest of Plutellaxylostella.

This study was conducted in the Laboratory of Agriculture Faculty of Flores University in Ende. A complete random design was employed with five treatments, namely J0 (aquades), J1 (75 ml of Pulai stem extract concentration), J2 (100ml of Pulai stem extract concentration), J3 (125ml of Pulai stem extract concentration), J4 (150ml of Pulai stem extract concentration).

The result of study reveals that extract of PulaiAlstoniascolaris stem was influential to the development of Plutellaxylostella pest in contact poison of $\mathrm{J} 07,50 \%$, J1 60,00\%, $\mathrm{J} 267,50 \%$, J3 67,50\% and $\mathrm{J} 480,00 \%$, while for reppellant activityof $\mathrm{J} 0$ 80,00\%, J1 $57,50 \%, \mathrm{~J} 222,50 \%, \mathrm{~J} 3 \mathrm{15}, 00 \%$, and $\mathrm{J} 415,00 \%$, for belly poison of $\mathrm{J} 0$ 00,00\%, J1 $57,50 \%, \mathrm{~J} 272,50 \%, \mathrm{~J} 375,00 \%$ and $\mathrm{J} 480,00 \%$. Extract of Pulai stem isthe right plant which is effective to highest mortality of Plutellaxylostellapest, belly poison on $80,00 \%$ of $\mathrm{J} 4$ treatment, repellant activity on $15 \%$ of $\mathrm{J} 4$ treatment, and contact poison on $70 \%$ of $\mathrm{J} 4$ treatment.
\end{abstract}

Keywords: Effectiveness of Pulai stem extract, Plutellaxylostella.

\section{PENDAHULUAN}

Kubis (Brassica oleracea)

merupakan tanaman sayuran family

Brassiceae yang mulanya merupakan

tanaman pengganggu atau gulma yang

tumbuh liar disepanjang laut tengah, di

karang-karang pantai Inggris. Produksi

kubis pada tahun 2011 total produksi sebesar 1.363.741 ton dengan luas lahan

67.323 ha, total produktifitasnya 20,08

ton/ha. Untuk propinsi NTT total produksi 883 ton dengan luas lahan 137

ha, total produktifitasnya 6,45 ton/ha

(BPS Ende, 2011).

Faktor penyebab penurunan hasil dalam budidaya tanaman kubis salah 
Yustina: Uji efektivitas ekstrak kulit batang pulai (Alstonia scolaris) terhadap hama Plutella xylostella

satunya adalah adanya serangan menimbulkan kerusakan lingkungan

Organisme Pengganggu Tanaman (Untung, 2006). Untuk meminimalisir

(OPT), terutama hama Plutella hal tersebut yaitu dengan penggunaan

xylostella. Stadium yang merusak pestisida nabati atau insektisida nabati.

tanaman kubis adalah larvanya. Larva Salah satu tanaman yang dapat

ini akan merayap kepermukaan daun dijadikan sebagai pestisida nabati yaitu

dan melubangi epidermis atau daging tanaman pulai (Alstonia scolaris) yang

daun. Serangan berat terjadi pada merupakan tanaman dari family

musim kemarau, saat tanaman berumur

Apocynaceae. Hasil penelitian

5-8 minggu (Rukmana, 2004). sebelumnya menyebutkan bahwa kulit

Kerusakan akibat hama Plutella batang pulai mampu menyebabkan efek

xylostella mengakibatkan kehilangan antiradang pada hama tikus putih, hasil 50-80\%.

karena pada tanaman ini memiliki

Pengendalian yang umumnya kandungan seperti saponin, alkaloid,

dilakukan oleh petani yaitu dengan flavonoid, dan tanin (Mashudi, 2005).

penggunaan bahan kimia karena Bahan-bahan ini merupakan sisa

dianggap lebih efektif dan efisien. metabolisme tumbuh-tumbuhan dan

Namun penggunaan insektisida sintetis digunakan untuk menjalankan peran

dapat menimbulkan dampak negatif ganda, seperti menarik serangga atau

seperti munculnya resistensi, mengusir serangga. Aroma yang

terbunuhnya parasit dan predator, residu ditimbulkan oleh senyawa-senyawa

pada bahan makanan, berbahaya bagi tersebut diduga mampu menolak

pemakai dan konsumen serta kehadiraan hama (Utami, 2003). Hasil 
Yustina: Uji efektivitas ekstrak kulit batang pulai (Alstonia scolaris) terhadap hama Plutella xylostella

pra penelitian menunjukkan bahwa

ekstrak kulit batang pulai dengan kosentrasi ekstrak $100 \mathrm{ml}$ menyebabkan

mortalitas hama Plutella xylostella sebesar $80 \%$.

\section{METODE PENELITIAN}

\section{Tempat dan Waktu}

Penelitian ini dilaksanakan di Laboratorium Fakultas Pertanian Universitas Flores, Jalan Sam Ratulangi Kabupaten Ende. Waktu Penelitian dari bulan November 2013 sampai Januari 2014.

\section{Bahan dan alat}

Bahan - bahan yang digunakan yaitu kubis, larva Plutella xylostella instar I, aquades, dan ekstrak Alstonia scolaris.Alat - alat yang digunakan yaitu gelas ukur, cawan petri, pipet, toples pembiakan, mikroskop, blender, timbangan, kertas HVS, penggaris, pensil, bolpoint, spidol, labu erlemeyer, kertas label dan kamera.

\section{Rancangan Percobaan}

Rancangan yang digunakan dalam penelitian ini adalah Rancangan Acak Lengkap (RAL) dengan 5 perlakuan yaitu JO : Aquades, J1 : Konsentrasi ekstrak kulit batang pulai $75 \mathrm{ml}, \mathrm{J} 2$ : Konsentrasi ekstrak kulit batang pulai $100 \mathrm{ml}, \mathrm{J} 3$ : Konsentrasi ekstrak kulit batang pulai $125 \mathrm{ml}, \mathrm{J} 4$ : Konsentrasi ekstrak kulit batang pulai $150 \mathrm{ml}$. Setiap perlakuan diulang sebanyak 4 kali.

\section{Pelaksanaan Penelitian}

\section{Pra Penelitian}

Pra penelitian dilakukan untuk mengetahui interval waktu pengamatan dan lama pengamatan. Sebanyak 10 ekor larva Plutella xylostella dipilih ukuran yang sama dimasukan kedalam cawan petri tanpa perlakuan dan diamati sintasanya dan interval waktunya, sehingga diketahui 30 menit pertama Plutella xylostella mengalami mortalitas untuk racun kontak, 1 jam kemudian 
Yustina: Uji efektivitas ekstrak kulit batang pulai (Alstonia scolaris) terhadap hama Plutella xylostella

mortalitas terjadi pada racun perut, dan untuk repellan diketahui pada menit ke 30 terjadi kunjungan. Dan kemampuan hidup Plutella xylostella tanpa makan selama 1 hari. Dari hasil pra penelitian menunjukan konsentrasi $100 \mathrm{ml}$ ekstrak kulit batang pulai dapat menyebabkan mortalitas sebesar $80 \%$.

\section{Perbanyakan Plutella xylostella}

Perbanyakan Plutella xylostella dilakukan dengan cara mengambil larva Plutella xylostella dari tanaman kubis yang sudah terserang. Kemudian disimpan dalam toples plastic yang pada bagian sisi kanan dan kiri dilubangi dan ditutup dengan kain kasa untuk sirkulasi udara. Setiap larva diberi pakan berupa daun kubis dan pergantian daun dilakukan pada saat daun tidak Nampak segar lagi. Larva yang siap di uji adalah larva instar I.

\section{Proses Ekstraksi}

Kulit batang pulai (Alstonia scolaris) diambil dibersihkan lalu dicacah sebanyak $1 \mathrm{~kg}$ kemudian diblender. Hasil blenderan kemudian diperas dengan menggunakan kain serbet yang bersih untuk mendapatkan air perasanya sebanyak 600ml. Hasil perasan dipanaskan dengan api kecil selama kurang lebih 15 menit dan didinginkan. Setelah itu bahan diencerkan sesuai perlakuan yaitu : 75 ml ekstrak : $75 \mathrm{ml}$ aquades, $100 \mathrm{ml}$ ekstrak : $50 \mathrm{ml}$ aquades, $125 \mathrm{ml}$ ekstrak $25 \mathrm{ml}$ aquades, $150 \mathrm{ml}$ ekstrak.

\section{Variabel Pengamatan}

Variabel pengamatan dalam penelitian ini adalah perilaku Larva Plutella xylostella yang terinfeksi, aktivitas racun kontak, aktivitas racun perut, dan aktivitas repellan. 
Yustina: Uji efektivitas ekstrak kulit batang pulai (Alstonia scolaris) terhadap hama Plutella xylostella

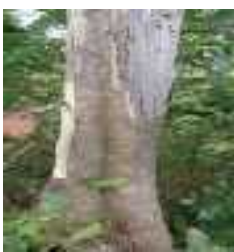

Pengambilan bahan kulit batang Pulai

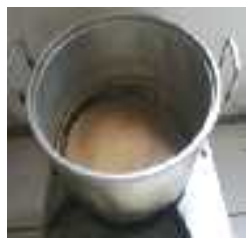

Pemanasan mengggunakan api

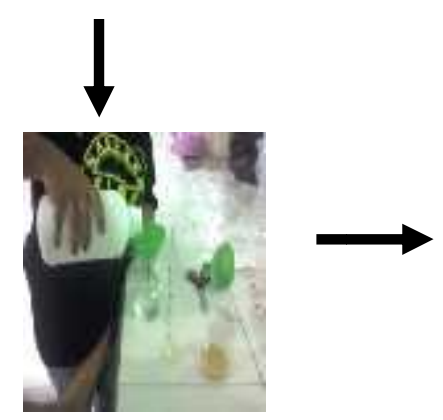

Pengenceran ekstrak sesuai perlakuan
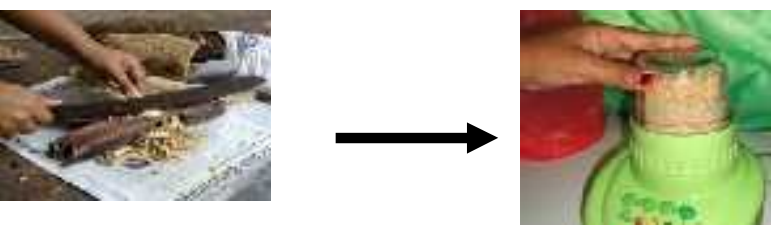

Pencacahan menggunakan parang

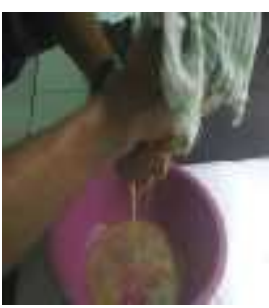

Penyaringan menggunakan kain serbet

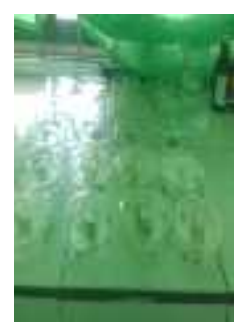

Aplikasi

Gambar 3.1 Proses Ekstraksi

\section{Analisis data}

Data yang terkumpul sebelum

dianalisis ditransformasikan dengan transformasi $\arcsin \sqrt{\mathrm{x}}$. Untuk melihat tingkat nyata pengaruh perlakuan dilanjutkan analisis sidik ragam dan apabila perlakuan menunjukan pengaruh yang sangat nyata maka 
Yustina: Uji efektivitas ekstrak kulit batang pulai (Alstonia scolaris) terhadap hama Plutella xylostella

dilanjutkan dengan uji BNT traraf 5\%

(Gomes dan Gomes, 1995).

\section{HASIL DAN PEMBAHASAN}

Hasil penelitian memperlihatkan bahwa aplikasi ekstrak kulit batang pulai menyebabkan mortalitas pada larva P. xylostella yang ditunjukkan dengan perubahan perilaku hama tersebut yaitu terjadi di 30 menit pertama - 30 menit ke-10 pada aktivitas racun kontak, pada aktivitas racun perut terjadi di 1 jam pertama -1 jam ke 10 , yang ditandai dengan pergerakannya yang cepat kemudian melambat, serta terjadi perubahan warna dari warna hijau menjadi kecoklatan dan bentuk tubuh menjadi pipih dan memanjang. Sedangkan pada perlakuan menggunakan aquades tidak terjadi perubahan baik dari pergerakan, warna maupun ukuran.

Hasil sidik ragam menunjukan bahwa ekstrak kulit batang Pulai memperlihatkan pengaruh yang sangat nyata terhadap mortalitas hama Plutella xylostella pada aktivitas racun kontak dan racun perut (Tabel 4.1).

Perlakuan ekstrak kulit batang pulai $150 \mathrm{ml}$ (J4) menyebabkan mortalitas hama paling tinggi. Hal tersebut diakibatkan kandungan bahan aktif lebih banyak dibandingkan perlakuan lainnya. Semakin tinggi jumlah bahan aktif yang terkandung, maka racun yang mengenai tubuh larva akan bekerja efektif. Hal tersebut diakibatkan adanya kandungan senyawa yang terdapat dalam kulit batang Pulai seperti alkaloid, dan saponin. Senyawa alkaloid adalah bahan organik yang mengandung nitrogen sebagai bahan dari sistem heterosiklik. Alkaloid bersifat basa yang mengandung satu atau lebih atom nitrogen, biasanya sebagai gabungan dari sistem siklik dan pada umumnya mengandung oksigen. 
Yustina: Uji efektivitas ekstrak kulit batang pulai (Alstonia scolaris) terhadap hama Plutella xylostella

Tabel 4.1 Mortalitas Plutella xylostella pada setiap perlakuan konsentrasi ekstrak kulit batang Pulai akibat aktvitas racun kontak dan racun perut (\%).

\begin{tabular}{ccc}
\hline & MORTALITAS $(\%)$ & \\
\hline \multirow{2}{*}{ Perlakuan } & Racun & Racun \\
& Kontak & Perut \\
\hline J0 & $7,50 \mathrm{~d}$ & $0,00 \mathrm{~d}$ \\
J1 & $60,00 \mathrm{c}$ & $57,50 \mathrm{c}$ \\
J2 & $67,50 \mathrm{~b}$ & $72,50 \mathrm{~b}$ \\
J3 & $67,50 \mathrm{~b}$ & $75,00 \mathrm{~b}$ \\
J4 & $70,00 \mathrm{a}$ & $80,00 \mathrm{a}$ \\
\hline BNT & 7,59 & 9,33
\end{tabular}

Keterangan : angka - angka yang diikuti huruf yang sama pada kolom yang sama berarti tidak berbeda nyata pada uji BNT taraf 5\%. Data ditransformasikan dengan $\operatorname{arscin} \sqrt{\mathrm{x}}$.

Senyawa alkaloid banyak Sehingga semakin tinggi konsentrasi terkandung dalam akar, biji, kayu suatu senyawa, maka jumlah racun yang maupun daun dari tumbuhan. Peran mengenai kulit larva semakin banyak, alkaloid bagi tumbuhan sebagai zat sehingga dapat menghambat racun yang melindungi tumbuhan dari pertumbuhan dan menyebabkan gangguan serangga, produk akhir reaksi kematian larva lebih banyak (Supeno, detoksifikasi hasil metabolisme. 2005).

Kebanyakan ditemukan dalam bentuk Senyawa Saponin yang amin $\left(-\mathrm{NR}_{2}\right)$ dan amida $\left(-\mathrm{CO}-\mathrm{NR}_{2}\right), \quad$ terkandung dalam kulit Batang Pulai dan tidak pernah dalam bentuk nitro memiliki aktivitas racun kontak $\left(\mathrm{NO}_{2}\right)$. Alkaloid bersifat basa, larut langsung bekerja ketika terjadi kontak dalam air dan diketahui dapat antara larva dan mengalami perubahan menghambat sintesis protein dan aktivitas mulai dari pergerakkannya merusak fungsisel (Triharso 2004). cepat dan kemudian melambat dan 
Yustina: Uji efektivitas ekstrak kulit batang pulai (Alstonia scolaris) terhadap hama Plutella xylostella

kaku. Senyawa tersebut masuk melalui kutikula, atau trakhea atau langsung mengenai mulut larva dan menembus integument (Kardinan, 2002). Saponin bersifat racun, antioksidan, antikarsinogenik merupakan salah jenis senyawa yang cukup aktif yang dapat menghambat perkembangan Plutella xylostella melalui proses menganggu pencernaan dan reproduksi larva, hal ini disebabkan oleh adanya sifat daya antifeedant dan repellent terhadap Larva Plutella xylostella. Daya antifeedant dapat menyebabkan larva tidak mau bertelur atau menolak memakan media pada masa infestasi (Wardhani, 2004). Senyawa saponin bersifat sebagai racun dan antimikroba (jamur, bakteri, virus), bahan aktif yang memiliki sifat daya larut lebih tinggi dalam air akan mudah menembus lapisan fosfolipid membran sel sehingga lebih cepat menganggu fungsi fisiologis yang pada akhirnya sel akan mengalami kematian (Ekawati, 2008). Ditinjau dari toksisitas, suatu senyawa dikatakan efektif bila mampu mematikan $80 \%$ hewan uji (Murfon dan Norton 1984 dalam Budiarto, 2000), oleh sebab itu perlakuan ekstrak kulit batang pulai $100 \mathrm{ml}$ (J4) diangap efektif karena mampu meningkatkan mortalitas $80 \%$.

\section{Aktivitas repellan Plutella xylostella}

Hasil sidik ragam menunjukan bahwa perlakuan ekstrak kulit batang pulai terahadap aktivitas repellan berpengaruh sangat nyata. Hal ini dapat dilihat pada tabel 4.4 terjadi kunjungan pada 30 menit pertama sampai 30 menit ke-7 (Tabel 4.2).

Perlakuan konsentrasi ekstrak kulit batang pulai $125 \mathrm{ml}$ (J3) dan 150 ml (J4) lebih efektif menurunkan aktivitas repelan Plutella xylostella $15 \%$ sedangkan untuk J0 tidak menurunkan aktivitas repelan Plutella xylostella 
Yustina: Uji efektivitas ekstrak kulit batang pulai (Alstonia scolaris) terhadap hama Plutella xylostella

80\%. Hal ini disebabkan oleh bahan aktif. Ekstrak kulit batang Pulai kandungan bahan aktif yang terdapat memiliki aroma yang menyengat, dan dalam kulit batang pulai yaitu senyawa dapat mempengaruhi sistem syaraf Tanin. Senyawa Tanin mempunyai serta dapat mengusir larva Plutella aroma yang menyengat sehingga larva xylostella.

tidak berkunjung dan menghindari dari

Tabel 4.2 Efektifitas Estrak Kulit Batang Pulai terhadap Hama Plutella xylostella pada Variabel Pengamatan Aktivitas Repellan Kunjungan (\%).

\begin{tabular}{cc}
\hline Perlakuan & Aktivitas Repellan \\
\hline J0 & $80,00 \mathrm{a}$ \\
J1 & $57,50 \mathrm{~b}$ \\
J2 & $22,50 \mathrm{c}$ \\
J3 & $15,00 \mathrm{~d}$ \\
J4 & $15,00 \mathrm{~d}$ \\
BNT & 5,86 \\
\hline
\end{tabular}

Keterangan : angka - angka yang diikuti huruf yang sama pada kolom yang sama berarti tidak berbeda nyata pada uji BNT taraf 5\%. Data ditransformasikan dengan $\operatorname{arscin} \sqrt{ } \mathrm{x}$.

Ekstrak kulit batang Pulai dapat mempengaruhi, melalui berbagai macam cara diantaranya menghambat perkembangan telur, larva atau pupa, menghambat pergantian kulit pada stadia larva, penolak makan, mencegah betina meletakkan telur, mengurangi nafsu makan atau memblokir kemampuan makan, menghambat reproduksi Penurunan jumlah total populasi Plutella xylostella, ini kemungkinan dapat disebabkan karena adanya pemberian perlakuan ekstrak kulit batang pulai yang mengandung senyawa Tanin dan Saponin (Kardinan, 2005).

\section{Kesimpulan}

1. Efetivitas ekstrak kulit batang Pulai Alstonia scolaris berpengaruh terhadap perkembangan hama 
Yustina: Uji efektivitas ekstrak kulit batang pulai (Alstonia scolaris) terhadap hama Plutella xylostella

Plutella xylostella sebagai Racun kontak J0 7,50\%, J1 60,00\%, J2 $67,50 \%, \mathrm{~J} 367,50 \%$ dan J4 80,00\% sedangkan untuk Aktivitas Repelan J0 80,00\%, J1 57,50\%, J2 22,50\%, J3 15,00\%, dan J4 15,00 \% sebagai racun Perut $\mathrm{J} 0$ 00,00\%, J1 57,50\%, $\mathrm{J} 272,50 \%$, J3 $75,00 \%$ dan $\mathrm{J} 4$ $80,00 \%$

2. Ekstrak kulit batang Pulai mengakibatkan mortalitas hama Plutella xylostella paling tinggi racun perut pada perlakuan J4 $80,00 \%$, racun kontak $\mathrm{J} 470,00 \%$, dan aktifitas repellan J4 $15 \%$.

\section{UCAPAN TERIMA KASIH}

Pada kesempatan ini penulis ingin mengucapkan terima kasih kepada semua pihak yang telah membantu dengan caranya masing-masing dalam melengkapi tulisan ini.

\section{DAFTAR PUSTAKA}

Anonim. 2012. Laporan Dasar-Dasar Perlindungan Tanaman. http:// ekaboymaster. Blogspot . com. Laporan dasar-dasr perlindungan tanaman. Html. Disidir 14 april 2013.

\begin{tabular}{l} 
2011. Pohon Pulai. \\
\hline http://darmation.blogspot. Com. \\
Pohon-pulai-alstonia-scolaris. \\
html. Disidir 14 april 2013 \\
2009. Pengendalian Hama \\
dan Penyakit Dengan Pestisida \\
Nabati. \\
Http://gapoktanimaju.blogspot.co \\
m/2009/01/pestisida- \\
nabati.html.disidir tanggal 27 \\
Desember 2013
\end{tabular}

Aminah N.S.Singgih H.,Soetiyono P.,Chaorul.2001. S.rarak, D.Metel dan E.Prostati Sebagai Larvasida Aedes Aegupti.Cermin Dunia Kedikteran No.131.

Arnason, J.T., S. Mackinnon, A. Durst, B.J.R. Philogene, C. Hasbun, P. Sanchez, L. Poveda, L. San Roman, M.B. Isman, C. Satasook, G.H.N. Towers, P. Wiriyachitra, J.L. $\quad$ McLaughlin. 1993. Insecticides in Tropical Plants with Non-neurotoxic Modes of Action. P. 107-151. In K.R. Downum, J.T. Romeo, H.A.P. Stafford (eds.), Phytochemical Potential of Tropical Plants. New York: Plenum Press.

Badan Pusat Statistik. 2012. Data kubis Indonesia dan Nusa Tenggara Timur. Badan Statistik Kabupaten Ende.

Budiman, C.P. 1994. Kajian Manfaat Bahan Tanaman Famili Annonacea sebagai Pestisida Nabati Alami untuk pengendalian organise pengganggu tumbuhan. Kumpulan makalah seminar pemanfaatan bahan alami dalam upaya pengendalian Hama berpadu dan Dinktorat Bina 
Yustina: Uji efektivitas ekstrak kulit batang pulai (Alstonia scolaris) terhadap hama Plutella xylostella

Perlindungan Tanmaman pangan. Jakarta

Ekawati, Intan W. 2008. Pengaruh Empat Jenis Ekstrak Tanaman Terhadap Aktivitas Peneluran. Skripsi. IPB. Bogor.

Gomez, Kwanchai A. dan Arturo A. Gomez. 1987. Prosedur Statistik untuk Penelitian Pertanian. Universitas Indonesia Press. Jakarta

Hernani, 1998. Perngaruh Ekstrak Batang Brotowali terhadap Aktivitas Biologi Hama Plutella xylostella. Skripsi. IPB. Bogor.

Kardinan, 2002. Pertisida Nabati Ramuan dan Aplikasinya.: Jakarta : Swadaya.

Kusnaedi, 1999. Pengendalian hama tanpa pestisida. Penebar Swadaya. Bogor

Novizan, 2004. Membuat dan Memanfaatkan Pestisida Ramah Lingkungan. Kanisius. Yogyakarta

Prijono, D. 1998. Pengujian Insektisida. Penuntun Praktikum Jurusan Hama dan Penyakit Tumbuhan Fak. Pertanian IPB. Bogor

Rahmawati Reny. 2012. Cepat dan Tepat Berantas Hama Penyakit Tanaman. Pustaka Baru Press. Yogyakarta

Riza, V. dan Tahjadi. 2001. Alternatif Pengendalian Hama. PAN Indonesia. Jakarta

Rukmana, R.2004. Budidaya Kubis Bunga Brocoli. Yogyakarta

Robinson, Trevor. 1995. Kandungan Organik Tumbuhan Tinggi. Edisi Keenam. Terjemahan Kokasih Patma Winata. Bandung : FMIPA ITB.

Slamet, M. 1995. Hama-hama Tanaman Pertanian Di Indonesia.
Yogyakarta : Yayasan Pembina Fakultas Pertanian Universitas Gaja Mada.

Sitepu, D., A. 2004. Pemanfaatan Pestisida Nabati. Journal Penelitian Tanaman Rempah dan Obat vol XI. No.2 diakses pada tanggal 02 Januari 2014.

Supeno, A. 2005, Pestisida nabati: Ramuan dan aplikasi. penabur swadaya, jakarta. 88 halaman

Triharso.2004. Pengendalian Hama dengan Menggunakan Inspktisida Nabati. Jakarta : PT. Penebar Swadaya

Untung Kasumbogo. 2006. Pengantar Pengelolaan Hama Terpadu. Gajah Mada University Press

Wardhani, RK. 2004 Pemanfaatan Tujuh Ekstrak Tumbuhan Sebagai Agens Pengendali Hama Plutella xylostella Motsch (Coleoptera: Curculionidae) Bogor : Jurusan Hama dan Penyakit Tumbuhan, Fakultas Pertanian, Institut Pertanian Bogor. 